Original Article

\title{
PROTECTIVE APTITUDE OF BORASSUS FLABELLIFER ROOT EXTRACTS AGAINST PARACETAMOL-INDUCED LIVER TOXICITY AND MYCOBACTERIUM TUBERCULOSIS (H37 RV)
}

\author{
VEDA PRIYA GUMMADI ${ }^{*}$, MALLIKARJUNA RAO TALLURI ${ }^{2}$, KEERTHANA DIYYA ${ }^{1}$, GANGA RAO BATTU ${ }^{1}$ \\ ${ }^{1}$ AU College of Pharmaceutical Science, Andhra University, Visakhapatnam, Andhra Pradesh 530003, ${ }^{2}$ Ana Cipher Clinical Research \\ Organization, Ramanthapur, Hyderabad, Telangana 500013 \\ Email: gummadi.veda88@gmail.com
}

Received: 29 Jul 2017 Revised and Accepted: 02 Nov 2017

\begin{abstract}
Objective: Borassus flabellifer is a doub palm tree, different parts of it have been using as food and in traditional medicine. The root parts (rhizomes) are used for phytochemical analysis and evaluation of hepatoprotective and anti-tuberculosis activities.

Materials: Hepatoprotective activity of Borassus flabellifer root extracts were studied on paracetamol induced liver toxicity in rats and antituberculosis activity on Mycobacterium tuberculosis [H37 Rv strain] quantitative determination using Microplate Alamar Blue assay (MABA) method.

Results: The phytochemical analysis of different extracts B. flabellifer roots showed the presence of sterols, terpenoids, glycosides, carbohydrates, proteins, flavonoids, alkaloids, phenols, tannins, saponins and oils. The methanolic extract showed more phenolic and alkaloid contents on their quantification. Ethyl Acetate, Chloroform and Methanol extracts of B. flabellifer showed the dose-dependent percentage protection of on paracetamol-induced liver toxicity. The methanol extract showed more activity and is comparable with standard drug Liv 52 on altered liver biomarker enzymes AST (SGOT), ALT (SGPT), ALP, total bilirubin and total protein levels with percentage protection 70.58\%, 68.91\%, 69.30\% $71.18 \%$ and $70.73 \%$. The ethyl acetate extract showed more anti-tuberculosis activity than methanol extract with MIC $6.25 \mu \mathrm{g} / \mathrm{ml}$ but the extracts showed lower activity compared to standard drugs ciprofloxacin, Streptomycin and pyrazinamide of the MIC values are $6.25,3.125,3.125 \mu \mathrm{g} / \mathrm{ml}$.
\end{abstract}

Conclusion: B. flabellifer roots possess different phytochemical constituents and those extracts possess hepatoprotective and anti-tuberculosis activities.

Keywords: Borassus flabellifer, Roots, Paracetamol, Liver, Tuberculosis

(C) 2017 The Authors. Published by Innovare Academic Sciences Pvt Ltd. This is an open-access article under the CC BY license (http://creativecommons.org/licenses/by/4.0/) DOI: http://dx.doi.org/10.22159/ijpps.2017v9i12.21692

\section{INTRODUCTION}

The liver is a vital organ in the human body, take part in ample metabolisms like carbohydrates, proteins, lipids metabolisms and mainly detoxification [1-2]. As of these functions, it is awful essential to maintain the liver healthy. But, different diseases (natural or druginduced), causing the liver failure finally leads to death [3-5]. Druginduced liver diseases (DILDs) are more common compared to natural liver diseases around the world [6-7]. The DILDs are cirrhosis, cancers, alcoholic liver diseases and non-alcoholic liver diseases are main causes for the liver failure [8-10]. Modern medical science developed many medicines for the treatment of liver diseases [11-12], and because of its regeneration capacity, the critical was liver transplantation [13]. But, all these treatments require drugs therapy. These treatments are not satisfactory and the long-term use of drugs may cause different side effects [14]. So, inadequate treatment of liver diseases and significant side effects of drugs, identification of new therapeutic agents are urgently needed. Herbal medicines provide significant formulations for treating various diseases including liver diseases with more efficient and minimize side effects [15-16]. In recent times, many researchers recognizing new drugs from different medicinal plants and those drugs are also precursors for synthesis new bioactive molecules for treating various diseases including liver diseases [17-18]. However, there was numerous medicinal flora were remained on the world without identification their medicinal uses.

Borassus flabellifer is a dumb palm tree belongs to the family resident to Indian sub-continent and Africa belongs to the family Arecaceae. Different parts of $B$. flabellifer have been using as medicine for diverse illnesses in traditional medicine [19]. Different phytochemical constituents like steroids, glycosides, vitamins etc were reported from B. flabellifer [20]. Different biological activities like cytotoxicity, antiarthritic activity, antibacterial activity, analgesic activity, antipyretic activity and hypoglycemic activity were reported by many researchers through their studies [21-24]. But, there were no scientific reports on the antioxidant activity of rhizome parts of B. flabellifer. In this regards, the present work carried out to evaluate the antioxidant activity of B. flabellifer rhizome (roots) part.

\section{MATERIALS AND METHODS}

Chemicals and drugs

The chemicals and solvents used in the current study were analytical grade. Diagnostic kits were purchased from span diagnostics Ltd, Gujarat, India. Silymarin was purchased from sigma chemicals, USA. Paracetamol tablets were purchased from the local medical shop.

\section{Preparation of extracts}

The B. flabellifer root pats were collected at near Bheemili region, Visakhapatnam, Andhra Pradesh and authenticated by the taxonomist Rtd. Prof. M. Venkaiah, Depart of Botany, Andhra University (AUCP/DP and P/BGR/BF-82). Freshly collected materials were dried under shade and then were milled to obtain a powder. The powdered material was separately extracted with different solvents ethyl acetate, chloroform and methanol successively using a Soxhlet apparatus. Finally, collected solutions were concentrated to dryness under vacuum by using Rota-vapor to get the dry extract and were stored in desiccators for further use.

\section{Phytochemical analysis}

The phytochemical analysis was carried out to B. flabellifer extracts using standard test procedures for identification of their chemical constituents [25].

\section{Total phenolic content}

Total phenolic content was determined using the folin-ciocalteau reagent. Briefly, folin-ciocalteau colorimetry is based on a chemical reduction of the reagent, a mixture of tungsten and molybdenum oxides. The products of the metal oxide reduction have a blue 
absorption with a maximum of $765 \mathrm{~nm}$. The intensity of the light absorption at that wavelength is proportional to the concentration of phenols. By using standard gallic acid calibration curve, measure the concentration of phenolic content in gallic acid total equivalents using unit's mg/gm. (GAE) [26-27].

\section{Total alkaloid content}

The plant extract $(1 \mathrm{mg} / \mathrm{ml})$ was dissolved in $2 \mathrm{~N}$ hydrochloric acid $(\mathrm{HCl})$ and then filtered. The $\mathrm{pH}$ of phosphate buffer solution was adjusted to neutrality with $0.1 \mathrm{~N}$ sodium hydroxide ( $\mathrm{NaOH}) .1 \mathrm{ml}$ of this solution was transferred to a separating funnel and then $5 \mathrm{ml}$ of Bromocresol green (BCG) solution along with $5 \mathrm{ml}$ of phosphate buffer was added. The mixture was shaken and the complex formed was extracted with chloroform by vigorous shaking. The extracts were collected in a $10 \mathrm{ml}$ volumetric flasks and diluted to volume with chloroform. The absorbance of the complex in chloroform was measured at $470 \mathrm{~nm}$. All experiments were performed thrice; the results were averaged and reported in the form of mean $\pm \operatorname{SEM}[26,28]$.

\section{Selection of animals}

Albino rats of single-sex weighing between 180-250 gm were obtained from M/s. Mahaveer Enterprises, Hyderabad, India. The animals were housed under controlled environmental conditions (temperature of $22 \pm 1{ }^{\circ} \mathrm{C}$ with an alternating $12 \mathrm{hr}$ light-dark cycle and relative humidity of $60 \pm 5 \%$ ), one week before the start and also during the experiment. They were fed with standard laboratory diet supplied by M/s. Rayans biotechnologies Pvt. Ltd., Hyderabad, and water ad labium during the experiment. Food was withdrawn $12 \mathrm{hr}$ before the terminating experiment and water were allowed adlibitum. The protocols were approved by Institutional Animal Ethics Committee and the lab was approved by CPCSEA, Government of India (Regd. No. 516/01/A/CPCSEA).

\section{Acute toxicity studies}

The acute toxicity study was conducted for extracts of B. flabellifer extracts as per OECD guidelines 423 (OECD.2001) and regulations. Albino rats of single-sex were selected into three groups of consisting of 6 animals. They were maintained for one week before the experiment, under room temperature and allowed free access to water and diet. The animals were subjected for acute toxicity study using each extract at a dose of $2000 \mathrm{mg} / \mathrm{kg}$ orally in 3 groups at regular intervals of time, i.e., 1, 2, 4, 8, 12 and $24 \mathrm{~h}$.

During this time, the animals were under observation to note different conditions like skin changes, morbidity, aggressiveness, oral secretions, sensitivity to sound and pain, respiratory movements and finally their mortality.

Evaluation of hepatoprotective activity using paracetamolinduced hepatotoxicity

Paracetamol-induced hepatotoxicity in rats' model was used for evaluation of hepatoprotective activity for the B. flabellifer extracts
[29]. Animals were divided into twelve (XII) groups $(\mathrm{N}=6)$. The animals of Group I served as control (vehicle) were given only saline ( $2 \mathrm{ml} / \mathrm{kg}$ b.w., per orally) for seven days. The animals of group II were administered with $2 \% \mathrm{w} / \mathrm{v}$ solution in water for $7 \mathrm{~d}$. The animals of group III were administered with Liv 52 (25 mg/kg per day, p. o.) for 7 d. Group IV to XII animals was administered with Ethyl acetate, Chloroform and methanol extracts of B. flabellifer (125, 250 and 500 $\mathrm{mg} / \mathrm{kg}$ respectively) for $7 \mathrm{~d}$. Except group I, all groups were administered with paracetamol $(200 \mathrm{mg} / \mathrm{kg}$ b.w., s. c.) as a $2 \% \mathrm{w} / \mathrm{v}$ solution in water on the 5 th day. Rats of all the groups were anaesthetized by chloroform, after $48 \mathrm{hr}$ paracetamol administrations. The blood was collected from the retro-orbital plexus and the collected blood samples were immediately centrifuged at 2400rpm for $15 \mathrm{~min}$. When serum clearly separated out, the serum was analyzed for AST (SGOT), ALT (SGPT), ALP, total bilirubin and total protein levels using commercial diagnostics reagent kits and Autoanalyzer [26]. After collection of blood samples, animals were sacrificed and the liver was collected, washed with saline and were stored in $10 \%$ formalin for histopathological studies.

\section{Histopathological studies}

Histopathological studies of the liver were performed by cutting 5 $\mathrm{mm}$ sections of the tissues by using a microtome and fixing in $10 \%$ formalin solution and staining with haemotxylin and eosin [30].

\section{Statistical analysis}

All the data were expressed as mean \pm SEM. Results were analysed by using Two-way ANOVA followed by Dunnet's multiple comparison test. All groups were compared with Liv 52 groups. ${ }^{* * *} \mathrm{p}<0.001$; ${ }^{* *} \mathrm{p}<0.01 ;{ }^{*} \mathrm{p}<0.05 ; \mathrm{ns}=$ Non significance.

\section{Anti-tuberculosis activity}

The anti-tubercular activity of ethyl acetate and methanol extracts of B. flabellifer were assessed against M. tuberculosis [H37 RV strain: ATCC No-27294] using microplate Alamar Blue assay (MABA) [31]. Control wells without the tested extracts and sterility controls were assayed simultaneously. Briefly, $100 \mu \mathrm{l}$ of prepared extracts were mixed $100 \mu \mathrm{l} M$. tuberculosis reference strain $\mathrm{H} 37 \mathrm{Rv}$ and Middle Brook 7H9 broth was added to test (Drug/Control wells) in the first row wells. Then two-fold dilution was done with a micropipette to next wells and each concentration was tested as triplicates. Finally, each well was covered with paraffin and incubated at $37^{\circ} \mathrm{C}$ for 5 7 days. After incubation, $25 \mu \mathrm{l}$ of $0.02 \% \mathrm{w} / \mathrm{v}$ resazurin was added to each well and incubated again at the same conditions for color development. The growth of organisms was observed by visual using the alamar blue oxidation-reduction dye.

The dye generally indicated the cellular growth, in this nonfluorescent blue color oxidized and become fluorescent pink color. On reduction, visual pink color indicates the presence of mycobacterial grow. The confirmation of the activity, the extracts were screened to know the minimum inhibitory concentration (MIC) at 100 to $0.2 \mu \mathrm{g} / \mathrm{ml}$.

Table 1: Nature of phytoconstituents in different extracts of $B$. flabellifer

\begin{tabular}{|c|c|c|c|}
\hline \multirow[t]{2}{*}{ Phytochemical constituents } & \multicolumn{3}{|c|}{ B. flabellifer } \\
\hline & EAE & CE & ME \\
\hline Phytosterols & ++ & + & + \\
\hline Terpenoids & + & - & ++ \\
\hline Glycosides & + & + & ++ \\
\hline Saponins & - & - & + \\
\hline Flavonoids & - & ++ & + \\
\hline Tannins & + & + & + \\
\hline Carbohydrates & - & + & ++ \\
\hline Alkaloids & + & ++ & ++ \\
\hline Amino acids & - & - & + \\
\hline Oils & + & + & - \\
\hline Phenols & + & + & ++ \\
\hline \multirow{2}{*}{\multicolumn{4}{|c|}{,$+++=$ Present, $-=$ Absent }} \\
\hline & & & \\
\hline
\end{tabular}


Table 2: Total phenolic and alkaloid contents $(\mathrm{mg} / \mathrm{gm})$ of $B$. flabellifer extracts

\begin{tabular}{lll}
\hline Name of the extract & TPC $(\mathbf{m g} / \mathbf{g m}) \#$ & TAC $(\mathbf{m g} / \mathbf{g m}) \#$ \\
\hline Ethyl acetate & $06.23 \pm 1.54$ & $03.28 \pm 2.18$ \\
Chloroform & $10.46 \pm 0.32$ & $08.11 \pm 1.02$ \\
Methanol & $16.08 \pm 0.49$ & $13.75 \pm 1.45$ \\
\hline
\end{tabular}

* TPC= Total Phenolic content; TAC= Total alkaloidal content, \# Values are in mean \pm SEM

\section{RESULTS}

\section{Phytochemical analysis}

B. flabellifer extracts exposed the presence of different phytochemical constituents on phytochemical analysis. The extracts revealed the presence of different phytochemical constituents like sterols, terpenoids, glycosides, carbohydrates, proteins, flavanoids, alkaloids, phenols, tannins, saponins and oils. The extracts gave different results for different phytochemical tests (table 1). The quantitative estimation of phenolic and alkaloid contents in three different extracts was varied, methanolic extract showed more content compared to chloroform and ethyl acetate extracts (table 2).

\section{Acute toxicity studies}

The extracts of B. flabellifer roots were tested for the toxicity at a dose of $2000 \mathrm{mg} / \mathrm{kg}$ and observed they are safe because there was no sign of mortality and no behavioural changes in the extracts administered group rats.

\section{Hepatoprotective activity}

Ethyl acetate, chloroform and methanol extracts of $B$. flabellifer were assessed at doses of $125 \mathrm{mg} / \mathrm{kg} \mathrm{b} . \mathrm{w}, 250 \mathrm{mg} / \mathrm{kg} \mathrm{b}$. w and $500 \mathrm{mg} / \mathrm{kg}$ b. $\mathrm{w}$ on Paracetamol-induced liver toxicity in rats for their hepatoprotective activity. The percentage protection produced by the standard (Liv 52) and extracts of B. flabellifer was calculated based on SGOT, SGPT, ALP, Total serum bilirubin and total protein levels in end of the experiment in each case (table 3).

Group I was treated with vehicle showed no significant changes, group II was treated paracetamol, there is a significant changes (Negative), The animals of group III was induced with paracetamol and was treated Liv 52 (Positive) showed the significant restoration with percentage protection $94.79 \%, 92.97 \%, 96.49 \%, 97.57 \%$ and $90.24 \%$ in levels of biomarker enzymes of liver (AST (SGOT), ALT (SGPT), ALP, total bilirubin and total protein) levels.

The percentage protection produced by ethyl acetate extract (BFEAE) on AST (SGOT), ALT (SGPT), ALP, total bilirubin and total protein levels at $125 \mathrm{mg} / \mathrm{kg}, 250 \mathrm{mg} / \mathrm{kg}$ and $500 \mathrm{mg} / \mathrm{kg}$ b. w were $11.66 \%, 10.16 \%, 9.62 \% 11.28 \%$ and $13.41 \%, 28.12 \%, 30.31 \%$ $28.34 \%, 31.25 \%$ and $29.27 \%, 51.3 \%, 47.19 \%, 50.96 \% 48.61 \%$ and $53.66 \%$ respectively (fig. 1 ).

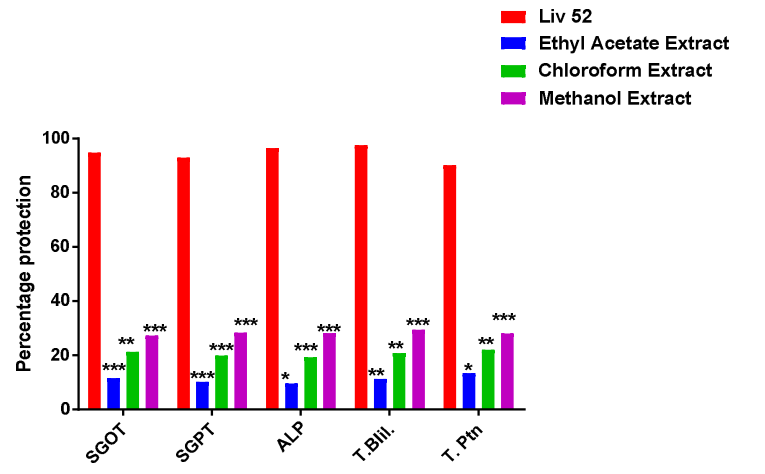

Fig. 1: Percentage protection produced by different extracts of $B$. flabellifer at a dose of $125 \mathrm{mg} / \mathrm{kg}$, Results were analysed by using Two-way ANOVA followed by Dunnet's multiple comparison test. All groups were compared with Liv 52 groups, ${ }^{* * *} \mathbf{p}<0.001 ; * * \mathbf{p}<0.01 ;{ }^{*} \mathbf{p}<0.05 ; \mathrm{ns}=$ non significance $(\mathrm{N}=6), \mathrm{T}$. Bil= Total bilirubin; $T$. $P t n=$ total protein
The percentage protection produced by the chloroform extract (BFCE) on AST (SGOT), ALT (SGPT), ALP, total bilirubin and total protein levels were $21.26 \%, 19.84 \%, 19.20 \% 20.83 \%$ and $21.95 \%$, $34.09 \%, 39.06 \%, 37.39 \% 41.67 \%$ and $42.68 \%, 58.85 \%, 58.91 \%$, $62.27 \% 65.97 \%$ and $62.80 \%$ respectively (fig. 2 ).

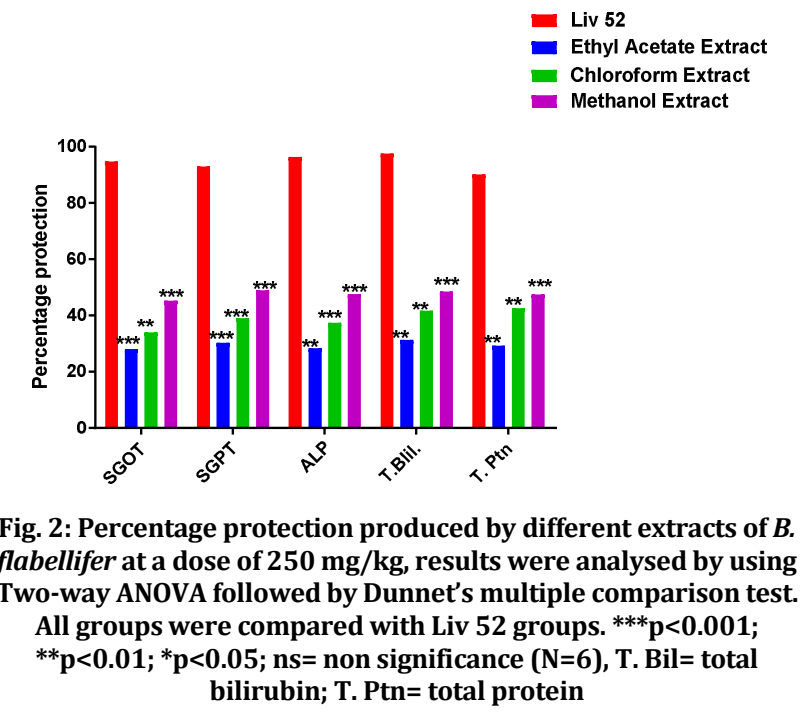

The percentage protection produced by the methanol extract (BFME) on AST (SGOT), ALT (SGPT), ALP, total bilirubin and total protein levels were $27.23 \%, 28.28 \%, 28.20 \% 29.51 \%$ and $28.05 \%$, $45.34 \%, 49.06 \%, 47.69 \% 48.61 \%$ and $47.56 \%, 70.58 \%, 68.91 \%$, $69.30 \% 71.18 \%$ and $70.73 \%$ respectively (fig. 3 ).

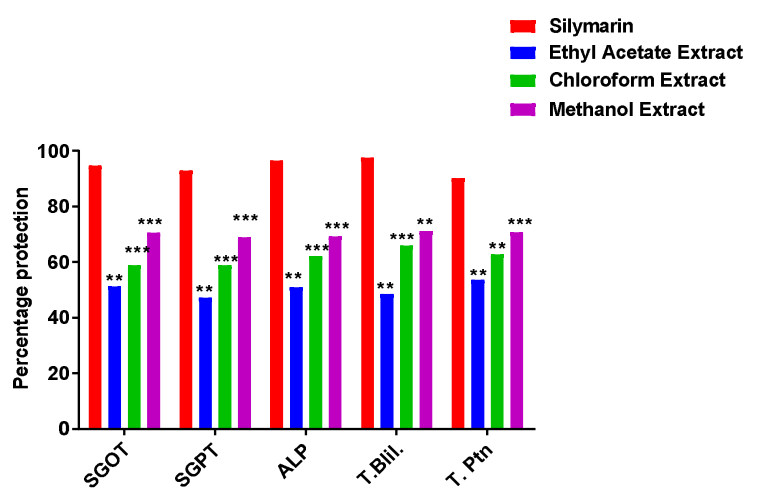

Fig. 3: Percentage protection produced by different extracts of $B$. flabellifer at a dose of $500 \mathrm{mg} / \mathrm{kg}$, results were analysed by using Two-way ANOVA followed by Dunnet's multiple comparison test. All groups were compared with Liv 52 groups. ${ }^{* * *} \mathbf{p}<0.001$; ${ }^{* *} \mathrm{p}<0.01 ;{ }^{*} \mathrm{p}<0.05 ; \mathrm{ns}=$ non significance $(\mathrm{N}=6), \mathrm{T}$. Bil= total bilirubin; T. Ptn= total protein

Histopathological studies performed in this study showed that, control group (treated with normal saline) animals showed the normal hepatic cellular structure with normal hepatic cells, well 
sinusoids. The paracetamol intoxicated liver (group II), shows evidence of the necrosis (fig. 4 (A)), haemorrhage and inflammation. These pathological changes were reduced in the retreated groups of animals treated with B. flabellifer extracts (fig. 4 (D and E) at different doses. The high dose of extracts i.e. $500 \mathrm{mg} / \mathrm{kg} \mathrm{b.w.} \mathrm{showed}$ more restoration of the damaged liver due to the paracetamol.

Table 3: Enzymes of levels of groups I to XII animals due to the effect of different extracts of $B$. flabellifer

\begin{tabular}{|c|c|c|c|c|c|}
\hline \multirow[t]{2}{*}{ Name of the drug } & \multicolumn{5}{|c|}{ Name of enzymes } \\
\hline & $\operatorname{AST}^{\#}(\mathrm{U} / \mathrm{l})$ & $\operatorname{ALT}^{\#}(\mathrm{U} / \mathrm{l})$ & $\operatorname{ALP}^{\#}(\mathrm{U} / \mathrm{l})$ & T. bil \# (mg/dl) & T. ptn" (gm/dl) \\
\hline Control & $89.17 \pm 1.11$ & $52.33 \pm 1.73$ & $183.50 \pm 0.85$ & $0.25 \pm 0.01$ & $6.93 \pm 0.06$ \\
\hline Paracetamol & $332.17 \pm 2.18$ & $173 \pm 5.22$ & $548.67 \pm 21.60$ & $2.17 \pm 0.06$ & $4.20 \pm 0.04$ \\
\hline Liv 5225 mg//kg b.w. & $101.83 \pm 1.72$ & $59.83 \pm 1.11$ & $195.67 \pm 1.56$ & $0.29 \pm 0.01$ & $6.67 \pm 0.08$ \\
\hline BFEAE $125 \mathrm{mg} / \mathrm{kg} \mathrm{b.} \mathrm{w}$ & $303.83 \pm 1.45$ & $148.17 \pm 1.08$ & $496.50 \pm 1.67$ & $1.95 \pm 0.07$ & $4.57 \pm 0.06$ \\
\hline$E A 250 \mathrm{mg} / \mathrm{kg} \mathrm{b.} \mathrm{w}$ & $263.83 \pm 2.24$ & $126.67 \pm 1.74$ & $431.67 \pm 1.38$ & $1.57 \pm 0.03$ & $5.00 \pm 0.05$ \\
\hline BFEAE $500 \mathrm{mg} / \mathrm{kg} \mathrm{b.} \mathrm{w}$ & $263.83 \pm 2.24$ & $108.67 \pm 1.05$ & $353.33 \pm 3.80$ & $1.23 \pm 0.06$ & $5.67 \pm 0.07$ \\
\hline BFCE $125 \mathrm{mg} / \mathrm{kg}$ b. w & $280.50 \pm 1.91$ & $148.17 \pm 1.08$ & $463.33 \pm 2.91$ & $1.77 \pm 0.06$ & $4.80 \pm 0.05$ \\
\hline BFCE $250 \mathrm{mg} / \mathrm{kg} \mathrm{b.} \mathrm{w}$ & $249.33 \pm 2.29$ & $117.33 \pm 1.52$ & $400.33 \pm 3.12$ & $1.37 \pm 0.06$ & $5.37 \pm 0.06$ \\
\hline BFCE $500 \mathrm{mg} / \mathrm{kg}$ b. w & $189.17 \pm 3.00$ & $96.17 \pm 1.74$ & $314.17 \pm 3.52$ & $0.90 \pm 0.04$ & $5.92 \pm 0.07$ \\
\hline BFME $125 \mathrm{mg} / \mathrm{kg} \mathrm{b.} \mathrm{w}$ & $266.00 \pm 1.93$ & $128.83 \pm 0.83$ & $432.17 \pm 1.83$ & $1.60 \pm 0.05$ & $4.97 \pm 0.08$ \\
\hline BFME $250 \mathrm{mg} / \mathrm{kg}$ b. w & $222.00 \pm 1.26$ & $106.67 \pm 1.33$ & $364.67 \pm 2.29$ & $1.23 \pm 0.06$ & $5.50 \pm 0.07$ \\
\hline BFME $500 \mathrm{mg} / \mathrm{kg} \mathrm{b.} \mathrm{w}$ & $160.67 \pm 1.33$ & $85.50 \pm 1.54$ & $289.83 \pm 2.79$ & $0.80 \pm 0.05$ & $6.13 \pm 0.04$ \\
\hline
\end{tabular}

\#Values are in mean $\pm \mathrm{SD}(\mathrm{N}=6)$

\section{Anti-tubercular activity}

The ethyl acetate and methanol extracts were evaluated for antitubercular activity because of less availability of chloroform extract. The result of in vitro antitubercular activity of extracts revealed that those extracts inhibited the growth of M. tuberculosis H37Rv at various at concentrations of $0.8-100 \mu \mathrm{g} / \mathrm{ml}$ (table 4 and fig. 5). The ethyl acetate extracts have more active compared to methanol extracts with MIC values 6.25 and $25 \mu \mathrm{g} / \mathrm{ml}$ and their results were comparable with standard drug ciprofloxacin.
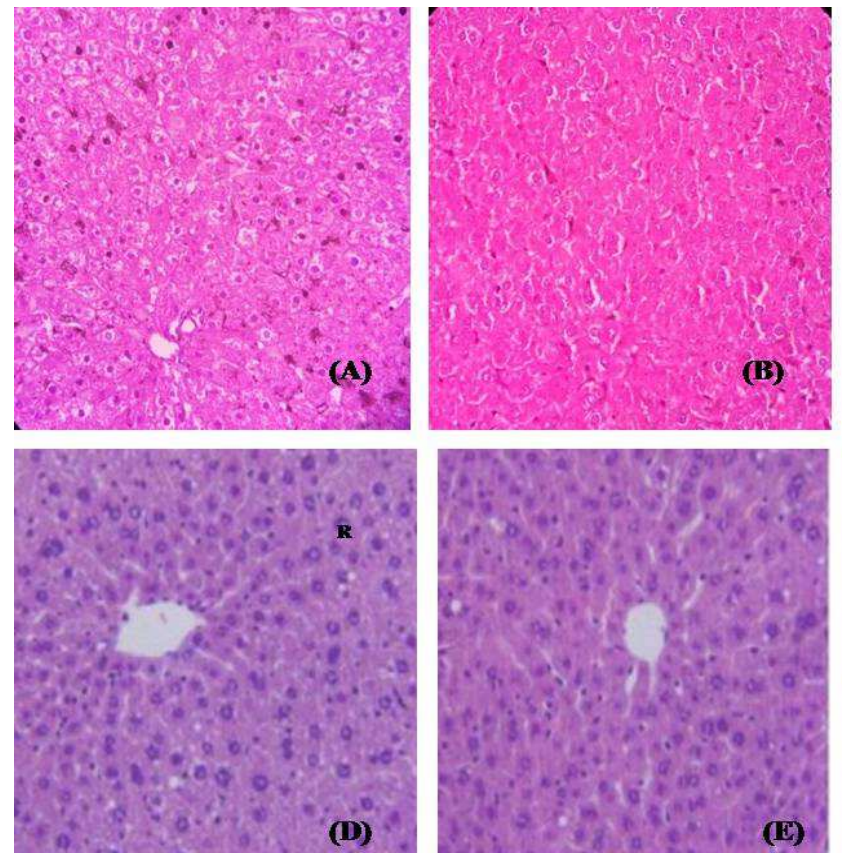
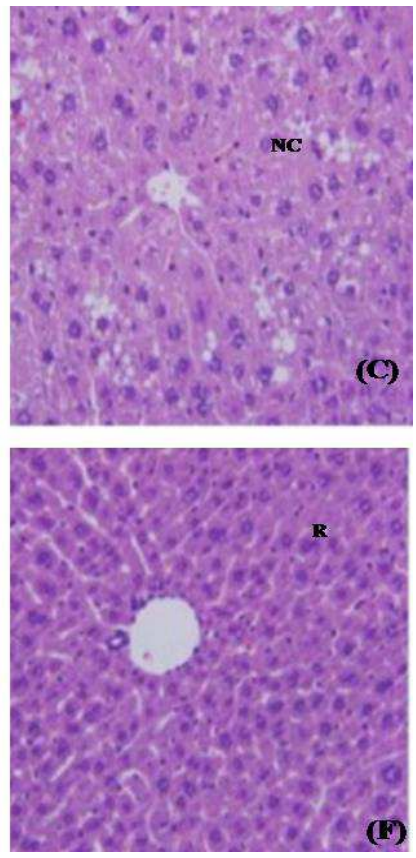

Fig. 4: Histopathological studies of liver tissue in different groups' animals in paracetamol-induced hepatotoxicity treated with different extracts of B. flabellifer, [A] control (Group I), [B] toxic group tissue without treatment (Group II), [C] Toxic group treated with Liv 52 (Group III), [D] toxic treated with BFEAE at $500 \mathrm{mg} / \mathrm{kg} \mathrm{b.w.} \mathrm{(Group} \mathrm{VI),} \mathrm{[E]} \mathrm{toxic} \mathrm{treated} \mathrm{with} \mathrm{BFCE} \mathrm{at} 500 \mathrm{mg} / \mathrm{kg}$ b.w. (group IX), [F] Toxic treated with BFME at $500 \mathrm{mg} / \mathrm{kg}$ b.w. (group XII), * NC-necrosis; R-regeneration

Table 4: Minimum inhibitory concentrations (MIC) of anti-tubercular activity of ethyl acetate and methanolic extracts of $B$. flabellifer

\begin{tabular}{ll}
\hline Sample name & Mycobacterium tuberculosis H37Rv strain MIC $(\boldsymbol{\mu g} / \mathbf{m l})$ \\
\hline BFEAE & 12.5 \\
BFME & 25 \\
Pyrazinamide & 3.125 \\
Streptomycin & 3.125 \\
Ciprofloxacin & 6.25 \\
\hline
\end{tabular}

BFEAE-B. flabellifer ethyl acetate extract; BFME-B. flabellifer methanol extract 


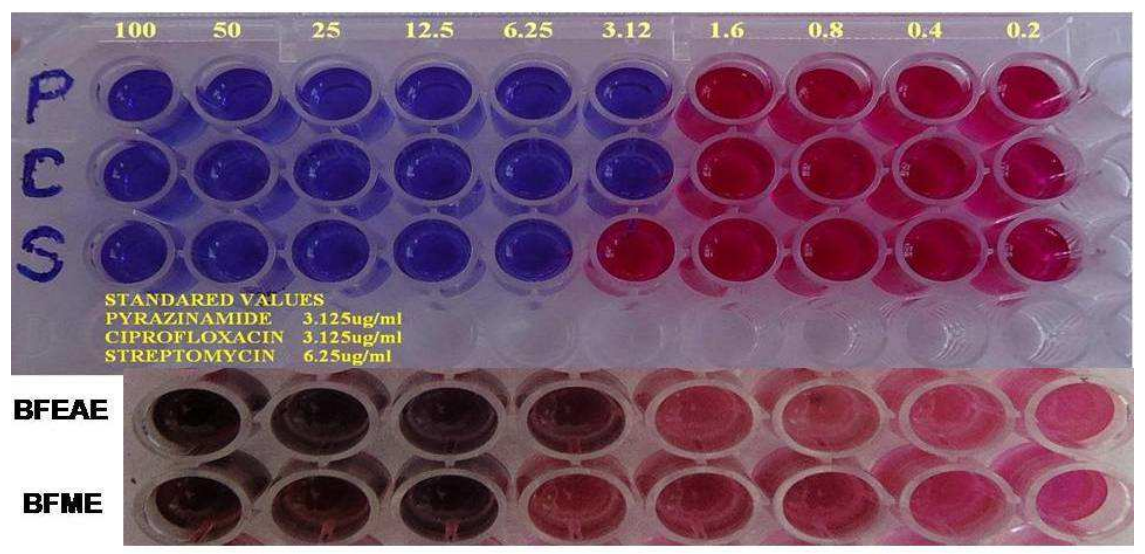

Fig. 5: the Anti-tubercular activity of ethyl acetate and methanolic extracts of $B$. flabellifer at different concentrations

\section{DISCUSSION}

In recent years, the study of ethno botanical and floristic characteristics of medicinal plants has been enhanced because of new diseases evolution, diseases causing microorganisms getting resistance to currently using drugs and cause of side effects in longterm use of modern medicines [32]. However, there was little known about the medicinal plants, which have been using traditional medicine and some of these medicinal plants were having scientific evidence [33]. In this point of view, the present work carried out on one of the medicinal plant (B. flabellifer) and different parts of it was used as food and in the treatment of diseases. But, there were very little works reported scientifically on root parts of B. flabellifer. The phytochemical analysis of different extracts $B$. flabellifer showed the presence of different phytochemical constituents like steroids, phenols, alkaloids, carbohydrates etc., in other parts' phytochemical analysis reported in fruits [34-35] and the phytochemical analysis of ethanolic extract of roots [36]. However, the results of present study mild differences were observed in the phytochemical analysis of ethanol, ethyl acetate and chloroform extracts, this may be due to regional variation of the $B$. flabellifer. There were some earlier reports about variation in the presence of different phytochemical constituents depends plants' growing region [37-39]. The methanolic extract showed the more phenolic and alkaloid contents compared to other extracts.

The extracts were tested for their safety before going to evaluate their hepatoprotective activity on animals, they were no mortality was found and at the maximum dose i.e. at $2000 \mathrm{mg} / \mathrm{kg}$ b.w. The current research, hepatoprotective activity of $B$. flabellifer root parts was an initial report on paracetamol-induced liver intoxication in rats. Ethyl acetate, Chloroform and Methanol extracts of $B$. flabellifer were showed dose-dependent hepatoprotective activity in the preventive treatment of liver intoxication with paracetamol. The extracts showed maximum protection at higher dose i.e. $500 \mathrm{mg} / \mathrm{kg}$ b.w. They have restored the liver biomarker enzymes (SGOT, SGPT, ALP, total bilirubin and total protein) levels compared to liver toxicity groups without any treatment (group II) and their protective effect was comparable with standard drug Liv 52. The protective effect of tested extracted was supported by liver histopathological studies on different group animals (fig. 4). Normal group animals were posses normally appear liver tissue with the good architecture of size, hepatic cells, but toxic group without treatment showed the inflammation, oversized, cirrhosis, haemorrhage and necrotic liver tissue with abnormal sinusoids and portal region. The other group's animals treated with ethyl acetate, chloroform and methanol extracts prevent the liver from above pathological conditions of the liver when paracetamol induction for liver toxicity and showed almost normal liver structure as a control group.

In our previous studies, these extracts showed antibacterial activity on different bacterial strains [40]. So, studies continued on antituberculosis activity using M. tuberculosis (H37 RV strain). The results of the present study showed good anti-tubercular activity and the results are comparable with the standard drugs ciprofloxacin and streptomycin. Interestingly, the ethyl acetate extract showed more anti-tubercular activity compared to hepatoprotective and antibacterial activity.

There have been different new drugs introducing for treating diseases and quick attaining of resistance towards them forcing researchers to identify new drugs from different with efficient activity and cost-effective [41]. The plants possess wide diversity of chemical constituents including steroids, alkaloids, phenols, glycosides and etc. Therefore, medicinal plants are still the main source for new therapeutic agents with less side effects, low cost, easy acceptance of patients and plants are cultivable without environmental pollution [42]. The results of the present study and previous studies by us demonstrating that $B$. flabellifer roots posses different bioactive compounds with different biological activities like antioxidant, antibacterial, hepatoprotective and like us, Titas Debnath et al. (2013) claimed that hypoglycemic activity of $B$. flabellifer roots [43]. It was may be assumed that extracts possesses antioxidant [44-46] and hepatoprotective activities against drugs induced hepatotoxicity. Furthermore, the B. flabellifer roots extracts showed anti-tuberculosis activity. However, the results obtained in the present study are warranted for further studies on different medicinal plants used as food and traditional medicine.

\section{CONCLUSION}

The present research reveals that B. flabellifer roots posses different phytochemical constituents and those extracts posses hepatoprotective and anti-tuberculosis activities and in our previous studies, these extracts reported about their antibacterial and antioxidant activities. The further work is needed to isolate and characterize the responsible bioactive molecules from these extracts as well as from different medicinal plants for development of effective and safe medicines.

\section{ACKNOWLEDGMENT}

The authors thankful to RGNF fellowship, UGC for their financial support, authorities of AU College of Pharmaceutical Sciences, Andhra University for providing the necessary facilities to complete present work and Director, Department of Molecular Biology and Immunology, Maratha Mandal's NGH Institute of Dental Sciences and Research Centre for their help in completion of Anti-tuberculosis activity.

\section{AUTHORS CONTRIBUTION}

1. Mallikarjuna Rao Talluri-correlated the results of experimental work and helped preparation of the manuscript.

2. Veda Priya and Keethana Diyya-designed the experimental work and performed lab work

3. B. Ganga Rao-guided how to plan the experimental design and monitored the lab work correlated the experimental findings with results of other workers and corrected the manuscript. 


\section{CONFLICT OF INTERESTS}

The authors report no conflicts of interest

\section{REFERENCES}

1. Jelkmann $\mathrm{W}$. The role of the liver in the production of thrombopoietin compared with erythropoietin. Eur J Gastroen Hepat 2001;13:791-801.

2. Sherif RZ, Abdel-Misih, Bloomston Mark. Liver anatomy. Surg Clin North Am 2010;90:643-53.

3. Zatonski WA, Sulkowska U, Manczuk M, Rehm J, Boffetta $\mathrm{P}$, Lowenfels $\mathrm{AB}$, et al. Liver cirrhosis mortality in Europe, with special attention to Central and Eastern Europe. Eur Addict Res 2010;16:193-201.

4. Hirschfield GM, Gershwin ME. The immunobiology and pathophysiology of primary biliary cirrhosis. Annu Rev Pathol 2013;8:303-30.

5. Dancygier, Henry K. Clinical hepatology principles and practice of hepatobiliary diseases. Springer; 2010. p. 895.

6. Sgro C, Clinard F, Ouazir K, Chanay H, Allard C, Guilleminet C, et al. Incidence of drug-induced hepatic injuries: a French population-based study. Hepatology 2002;36:451-5.

7. Hirschfield GM, Thain C, Walmsley M, Brownlee A, Jones DE. Liver disease in the UK. Lancet 2015;385:503.

8. Ali A Mokdad, Alan D Lopez, Saied Shahraz, Rafael Lozano, Ali H Mokdad, Jeff Stanaway, et al. Liver cirrhosis mortality in 187 countries between 1980 and 2010:a systematic analysis. BMC Med 2014;12:145.

9. O'Shea RS, Dasarathy S, McCullough AJ. Alcoholic liver disease. Am J Gastroenterol 2010;1:14-32.

10. Naveed S, Ewan F, David P. Non-alcoholic fatty liver disease. Br Med J 2014;349:g4596.

11. Chu J, Sadler KC. New school in liver development: Lessons from zebrafish. Hepatology 2009;50:1656-63.

12. Talwani R, Gilliam BL, Howell C. Infectious diseases and the liver. Clin Liver Dis 2011;15:111-30.

13. Bramstedt K. Living liver donor mortality: where do we stand? Am J Gastroenterol 2006;101:755-9.

14. Porceddu M, Buron N, Roussel C, Labbe G, Fromenty B, BorgneSanchez A. Prediction of liver injury induced by chemicals in human with a multiparametric assay on isolated mouse liver mitochondria. Toxicol Sci 2012;129:332-45.

15. Subbarayappa BV. The roots of ancient medicine: an historical outline. J Biosci 2001;26:135-43.

16. Hong M, Li S, Tan HY, Wang N, Tsao SW, Feng Y. Current status of herbal medicines in chronic liver disease therapy: the biological effects, molecular targets and future prospects. Int J Mol Sci 2015;16:28705-45.

17. Lodha R, Bagga A. Traditional Indian systems of medicine. Ann Acad Med Singap 2000;29:37-41.

18. Khokhlenkova NV, Kovalenko SM, Azarenko JM, Buryak MV. Development of methodical approaches to the creation of the pharmacologically active bandage. Asian J Pharm Clin Res 2017;10:20-4.

19. Veda Priya G, Ganga Rao B, Keerthana D, Kiran M. A review on palmyra palm (Borassus flabellifer). Int J Curr Pharm Res 2016;8:17-20.

20. Subashini S, Ramesh Kannan V, Mani P. Phytochemical and GCMS analysis of bioactive compounds from Borassus flabellifer Linn root. European J Mol Biol Biochem 2015;2:148-52.

21. Paschapur MS, Swathi P, Sachin RP, Ravi Kumar, Patil MB. Evaluation of the analgesic and antipyretic activities of ethanolic extract of male flower (inflorescences) of Borassus flabellifer L. (Arecaceae). Int J Pharm Pharm Sci 2009;1:98-106.

22. Sumudunie KA, Jansz ER, Sharmini J, Nalini Wickramasinghe SMD. The neurotoxic effect of palmyrah (Borassus flabellifer) flour re-visited. Int J Food Sci Nutr 2004;55:607-14.

23. Devi S, Arseculeratne SN, Pathmanathan R, McKenzie IF, Pang T. Suppression of cell-mediated immunity following oral feeding of mice with palmyrah (Borassus flabellifer L) flour. Aust J Exp Biol Med Sci 1985;63:371-9.
24. Kangwanpong D, Arseculeratne SN, Sirisinha S. Clastogenic effect of aqueous extracts of palmyrah (Borassus flabellifer) flour on human blood lymphocytes. Mutat Res 1981;89:63-8.

25. Trease G, Evans SM. Pharmacognosy. $15^{\text {th }}$ ed. Bailer Tindal, London, Elsevier Publisher; 2002. p. 23-67.

26. Rao BG, Rao YV, Rao TM. The hepatoprotective and antioxidant capacity of Melochia corchorifolia extracts. Asian Pac J Trop Med 2013;6:537-43.

27. Singleton VL, Rossi JA. Colorimetry of total phenolics with phosphomolybdic acid phosphotungstic acid reagents. Am J Enol Vitic 1965;16:144-58.

28. Fazel S, Hamidreza M, Rouhollah G, Verdian-rizi M. Spectrophotometric determination of total alkaloids in some Iranian medicinal plants. Thai J Pharm Sci 2008;32:17-20.

29. Ramachandra Setty S, Quereshi AA, Viswanath Swamy AH, Patil T, Prakash T, Prabhu K. Hepatoprotective activity of Calotropis procera flowers against paracetamol-induced hepatic injury in rats. Fitoterapia 2007;78:451-4.

30. Vidhya Malar HL, Mettilda Bai SM. Hepatoprotective activity of Phyllanthus emblica against paracetamol-induced hepatic damage in Wister albino rats. Afr J Basic Appl Sci 2009;1:21-5.

31. Collins L, Franzblau SG. Microplate alamar blue assay versus BACTEC 460 system for high-throughput screening of compounds against Mycobacterium tuberculosis and Mycobacterium avium. Antimicrob Agents Chemother 1997;41:1004-9.

32. Charlotte Harrison. Adverse drug reactions: computational model predicts side effects. Nat Rev Drug Discovery 2014;11:602.

33. Debbie Shaw, Ladds Graeme, Duez Pierre, Williamson Elizabeth, Chan Kelvin. Pharmacovigilance of herbal medicine. J Ethnopharmacol 2012;140:513-8.

34. Nikawala JK, Wijeyaratne SC, Jansz ER, Abeysekara AM. Flabelliferins, steroidal saponin from palmyrah fruit (Borassus flabellifer) pulp II. Preliminary studies on the effect on yeast and bacteria. J Natl Sci Found 1998;26:141-50.

35. Vengaiah PC, Vijaya kumara B, Murthy GN, Prasad KR. Physicochemical properties of palmyrah fruit pulp (Borassus flabellifer L). J Nutr Food Sci 2015;5:1-4.

36. Subashini S, Rameshkannan V, Mani P. Phytochemical and GCMS analysis of bioactive compounds from Borassus flabellifer Linn root. Eur J Mol Biol Biochem 2015;2:148-52.

37. Pascoal Neto C, Seca A, Nunes AM, Coimbra MA, Domingues F, Evtuguin D. Variations in chemical composition and structure of macromolecular components in different morphological regions and maturity stages of Arundo donax. Ind Crops Prod 1997;6:51-8.

38. Ganga Rao B, Mallikarjuna Rao T, Venkateswara Rao Y. The hepatoprotective and antioxidant capacity of Melochia corchorifolia extracts. Asian Pac J Trop Med 2013;6:412-20.

39. Jayanthy A, Prakash Kumar U, Remashree AB. Seasonal and geographical variations in cellular characters and chemical contents in desmodium gangeticum (L.) DC.-An ayurvedic medicinal plant. Int J Herb Med 2013;1:34-7.

40. Priya GV, Mallikarjuna Rao T, Ganga Rao B. Antibacterial activity of Borassus flabellifer. Peertechz J Biomed Eng 2016;1:3-5.

41. Gaurav Kumar Sharma. Studies on phytochemical constituents of medicinal plants. Am J Pharm Pharm Sci 2014;1:61-74.

42. Iqbal A, Mabood Husain F, Maheshwari M, Zahin M. Medicinal plants and phytocompounds: a potential source of novel antibiofilm agents. Antibiofilm Agents 2014;8:205-32.

43. Titas D, Radhakrishnan, Rajesh Gopal, Murugananthan T, Sahil Nandakumar K. Hypoglycaemic effects of alcoholic root extract of Borassus flabellifer (Linn.) in normal and diabetic rats. Pak J Pharm Sci 2013;26:673-9.

44. Gupta AK, Chitme H, Daa SK, Misra N. Hepatoprotective activity of Rauwolfia serpentine rhizome in paracetamol intoxicated rats. J Paint Technol 2006;1:82-8.

45. Ganga Rao B, Rajeswara Rao P, Prayaga Murthy P, Samba Siva Rao E, Praneeth D, Mallikarjuna Rao T, et al. Investigation on regional variation in total phenolic, alkaloid content and in vitro antioxidant activity of Leucas aspera. Int J Pharm Sci Res 2011;2:2699-703.

46. Mallikarjuna Rao T, Veda Priya G, Ganga Rao B. Antioxidant activity of Borassus flabellifer. Int Res J Pharm 2017;8:18-22. 